\title{
Public pastoral care as nexus and opportunity for a transformed practical theology within decolonisation discourse in South African higher education
}

\begin{abstract}
Author:
Vhumani Magezi ${ }^{1}$ (D)

Affiliation:

${ }^{1}$ Faculty of Theology,

North-West University,

South Africa

Corresponding author: Vhumani Magezi, vhumani@hotmail.com

Dates:

Received: 06 Nov. 2017

Accepted: 14 Mar. 2018

Published: 06 June 2018

How to cite this article: Magezi, V., 2018, 'Public pastoral care as nexus and opportunity for a transformed practical theology within decolonisation discourse in South African higher education', In die Skriflig 52(1), a2327. https://doi. org/10.4102/ids.v52i1.2327

\section{Copyright:}

(c) 2018. The Authors. Licensee: AOSIS. This work

is licensed under the

Creative Commons

Attribution License.
\end{abstract}

Read online:

\begin{abstract}
The discussion on decolonisation of universities that started in 2015 has been raging in different spaces within South Africa and other parts of the world. The question of the relevance of the curriculum in universities, which is a curriculum that is responsive to South African and African issues, has come to the forefront. The discipline of Theology has also been challenged to reflect on its curriculum. Given these developments, this article considers practical theology within the on-going discussion of decolonisation in South African universities. In doing so, it attempts to address the question: What are some of the issues to consider in decolonisation of practical theology in South Africa universities? Firstly, the article sketches the background to the context of the discussion. Secondly, it provides a synopsis of the discussion of decolonisation in universities. Thirdly, it highlights some colonial entanglements of practical theology evident from the current situation. Fourthly, it proposes pointers for basic steps towards decolonisation of practical theology. Fifthly, it concludes by highlighting the threats to the proposed decolonisation attempts. The article assumes a coloniality and decoloniality framework even though it is not explicitly stated.
\end{abstract}

\section{Introduction and background}

The African continent faces challenges that range from social, political and economic to religious issues. They include corruption, conflicts, oppression, migration, social injustice, weak rule of law, HIV and AIDS, and many other challenges (Gathogo 2007; Pengo 2011). Transparency International's Corruption Perception Index measures the perceived levels of public sector corruption worldwide, where 100 points indicate categorically no corruption and zero points indicates very high corruption. Every African country scores less than 50 points, except Botswana with 63, which is ranked 31st in the world. The global average score is 43 , while for sub-Saharan Africa it is 33 (Ernst \& Young 2014:9). It is worrying that $92 \%$ of sub-Saharan African countries scored below 50 points. Nussbaum observed that African political leaders have betrayed their fundamental humanness values (Nussbaum 2003:1). Further to the challenges experienced within general society, churches also experience challenges that are particular to them. Using an example of the Dutch Reformed Churches in South Africa (DRCSA), Sekhaulelo (2016:2-4) observed that the DRCSA churches are experiencing challenges that include the rise of South Africa as a secular state, religious pluralism, marginalisation of minorities, decline in membership commitment, legitimacy crisis and general moral decay. Far from being exhaustive, the above challenges are, however, a clarion call for attention in many African countries.

A concerted effort by various players is required to provide multifaceted responses. The players include politicians, community leaders, academic institutions, churches and other societal players. Our interest in this discussion is churches. Williams, the Archbishop of Canterbury, rightly maintained that churches as Christian communities should participate in activities that assist humanity to flourish. He (Williams 2011) stated that:

Christian community has to learn civic virtues that will create civic flourishing and to learn how to exercise those tasks of decision-making within community and maintaining and sustaining a human environment. (p. 2)

He argues that Christian communities cannot opt out of public and social issues, and existing challenges, but they should live out a different identity and vision in the world. This means that churches should attend to issues that directly affect the life and progress of people, and participate in addressing the socio-public issues such as corruption, governance, oppression, et cetera. The challenge for churches to respond to public issues is a concern for theological disciplines such as practical theology, public theology and pastoral care. 
It is useful to provide a synoptic description of these three theologies. Practical theology is an approach that focuses on ensuring that theology is useful and relevant to everyday concerns. Public theology focuses on the need for theology to interact with public issues of contemporary society. Pastoral care is concerned with providing care and support to people in pain and anxiety, including any other life situation. Practical theology is interconnected with public theology. Practical theology includes a public dimension in its work (Osmer \& Schweitzer 2003:215). However, Dreyer (2004) indicates that:

Not all practical theology is public theology, in other words aimed at a non-ecclesial general audience. Practical theology is also theology for the church, that is for a Christian audience, and is theology for an academic audience. (p. 919)

Dreyer (2004:919-920) advised that the days are long gone when the practices of the church and clergy were the main or the only focus of practical theology. The vision has broadened to include the context of everyday life on a local, national and global level. Osmer and Schweitzer (2003:218) usefully explained that the task of public practical theology is discerned in three ways: firstly, it is about ensuring that the public is one of the audiences of practical theology. Secondly, it is to ensure that practical theology includes everyday concerns and issues in its reflection. Thirdly, practical theology should facilitate a dialogue between theology and contemporary culture. In linking public theology and pastoral care, Koppel (2015) maintained that:

Practicing public theology asks that pastoral care practitioners and theologians take seriously and engage mindfully with issues that concern groups of people and whole populations, rather than individual persons in isolation. Framing pastoral care ministries, education, and institutions through this larger social lens helps theorists and practitioners to refine methods and purposes for our common work. (p. 151)

Thus public theology acts as a larger social lens that, in the process, should lead to framing pastoral care ministries (Koppel 2015:151). In practising public pastoral care, the pastor should be 'involved with people in and for the community' (Vanhoozer \& Strachan 2015:17). The pastor is a public figure in the community.

Gathogo's argument for African Reconstruction Theology (2007:119) provides a useful connection between practical theology and public theology as well as public theology and pastoral care in Africa. In an outline of African Reconstruction Theology, Gathogo (2007:119) advised that a theology of reconstruction in Africa is a wakeup call to theological practitioners (theologians and church leaders) in Africa to pursue an agenda that is pastorally holistic in society. The theme of shifting theology, particularly pastoral care from private spiritual nourishment to public space (MillerMcLemore 2005), is gaining currency. Koppel (2015:151) reported that the 2015 Society for Pastoral Theology Annual Study Conference, titled 'Practicing public pastoral theologies in contexts of difference', explored scholarly and practical dimensions for the exercise of public pastoral theology.
Lartey and Sharp (2015:134) added that this theme, 'Practicing public theologies in contexts of difference', was intended to encourage multiple public conversation partners to whom pastoral theology is accountable and implicated to engage each other in thoughtful dialogues. They added that responsible public pastoral practice requires negotiating complex tensions in communities. Thus, strategic public pastoral theology aims to foster both deep self-reflection and expansive global or even cosmic citizenry. The challenge, posed by the shift to public pastoral care, is, for theology, to effectively engage with social issues to participate in creating civic flourishing (Williams 2011:2-4) in addition to spiritual issues. Therefore, Vanhoozer and Strachan (2015:16-17) in The pastor as public theologian advised that the pastor should be a theologian by saying 'what God is saying in Christ'. At the same he or she should be a public figure which means that he or she should 'publicly be involved in and for the community'. Miller-McLemore (2005), in her essay, Pastoral theology and public theology describes the developments regarding the movement of pastoral care to public theology as: first, the concern about the silence of mainstream Christianity on key social issues; and second, awareness of the limitations of pastoral focus on the individual alone. Hence, this begs pastoral care to focus on the whole person and public issues.

Observing from the developments mentioned above, the call for theology, especially pastoral care (which is our focus) to engage in public issues, is evident. The gap in pastoral care, noted by Miller-McLemore (2005), of silence and focusing on individuals in the context where challenges and needs exist within the public spaces is deplorable. Juma (2015:3) states that public theology is about interpreting and living theological beliefs and values in the public realm. Public theology is about ensuring that theology engages with issues within public spaces and not only within the church. This includes that the role, function and contribution of churches is visible in the public sphere. In this sense, public theology is not a private theological study, but a visible evidence of what God is doing in communities through human agents belonging to churches. Jesus highlighted public visibility of Christian ministry by saying no one lights a lamp and puts it under a table (Mt 5:15).

Viewed from a public theology lens, pastoral care extends beyond spiritual nourishment and narrow diakonia care to engaging diverse issues affecting humanity ranging from politics, leadership, corruption, injustice, et cetera. It should be highlighted, as Miller-McLemore (2012:17) noted, that pastoral care as it is usually understood, particularly in the USA, narrowly focuses on human 'angst and its appropriation of psychology, persons and pain'. This pastoral perspective is different from the meaning of pastoral care as it is used in African Reconstruction Theology, which refers to theological exercise of holistically engaging life issues such as tribalism, oppression, HIV, gender, global warming, et cetera (Gathogo 2007:119). Louw (2008; 2014) advances the same notion of pastoral care as holistic life care. African Reconstruction Theology 'is pastoral in that it seeks to restore and address 
the challenges experienced in many African communities' (Gathogo 2007:101). This indicates that pastoral theology, in the sense of African reconstruction theology, is clearly practical theology. Miller-McLemore (2012:26) remarked that practical theology is about returning theology to the people. She added that, as an academic discipline, practical theology is secondary to the work and practice of most Christians and scholars. It is also primarily a way of doing theology in daily life that is fundamental to Christian faith.

Evident from the above discussion are the following challenges: first, the challenge for a theological approach that advances the good of life (Williams 2011); second, the challenge to engage and reconstruct structures for a better life of people (Gathogo 2007); and third, the need for pastoral care as human care (Louw 2014) that should be performed at the public space as ideal practical theology. In highlighting the contribution of practical theology to the field of theology, Miller-McLemore (2012:26) rightly stated that practical theology has disrupted the space occupied by academic theology by pushing for a fresh theology abstracted from life. It is about taking theology out to the streets and using what is learned from the streets to assess the adequacy of biblical, historical and doctrinal claims. Indeed, as Gathogo (2007) states, such an approach in Africa is about a theology that engages with holistic issues to develop and reconstruct Africa that addresses its issues head-on. Therefore, this calls for a relevance of theology - particularly practical theology - to the African continent. To ensure such relevance, practical theology should be disentangled from imported agendas and approaches that mimic Western theological projects. This calls for a decolonisation of practical theology to ensure that it engages with pressing public challenges, both for African Christianity and social development. But what is decolonisation and what are discernible elements that require decolonisation? What steps can be taken as an effort towards decolonising theology, particularly practical theology?

The argument advanced is that pastoral care, as a practical theology discipline, should shift from private care and narrow diakonia focus to the public domain as part of its public function. To that end, within higher education conversation on decolonisation, practical theology should use public pastoral care nexus as a contextual launch pad. Practical theology should be critical and self-reflective of its practices to reform its practices to be relevant and contribute in addressing South African and African challenges at large.

\section{Decolonisation discussion within South African universities}

The \#RhodesMustFall movement that started in early 2015 triggered a debate about decolonising academic space and curriculum. Max Price, the Vice Chancellor of the University of Cape Town (UCT) and Russell Ally, in their article, The challenge of decolonisation: UCT's transformation journey indicated that UCT will be radically transformed as a result of this development. They (Price \& Ally 2016) stated that a task team was established at the university to:

[b]egin the process of interrogating all the artwork and photographs in public spaces across the campus to consider and consult on what the university community as a whole would want to see celebrated, venerated and commemorated. This could begin a process of deep engagement and reflection on cultural diversity, affirming identity, and how to achieve an inclusive environment. (p. 2)

The Cecil John Rhodes statute was removed after one month of the movement at UCT. The movement also inspired other similar movements at the Stellenbosch, Rhodes and Wits Universities. The students called for a decolonisation of universities and the curricula. Decolonisation is an effort to undo colonisation. The proponents of decolonisation in universities argue that universities are dominated by colonial Eurocentric ideas, theories and approaches to knowledge. Heleta (2016:1) argues that these Eurocentric colonial ideas and approaches do not reflect lived experiences of black students. They do not reflect African stories in the classrooms. The Eurocentric ideas express colonial knowledge systems designed to denigrate and subjugate black people. This curriculum confronts black students with theories that negate their own lived experiences, dreams and aspirations. In focusing on Eurocentric approaches, Nyathi (2016) maintains that education is used as an instrument and vehicle of perpetuating colonisation and colonial hegemonies. Maldonado-Torres (n.d.:8) added that 'Education, including academic scholarship, national culture, and the media are three areas where this modern/colonial attitude tends to take hold and reproduce itself.' The persistence and sustaining hegemonic forces of colonial tendencies and practices is termed coloniality. ${ }^{1}$ Coloniality and decoloniality refer to the logic, metaphysics, ontology and matrix of power created by the massive processes of colonisation and decolonisation (Dreyer 2017; Maldonado-Torres n.d.; Mignolo 2011). Hence, what is referred to as decolonisation in this article is decoloniality.

In responding to the call for decolonisation of universities, some of the questions posed, reflect genuine inquiry to explore ways of addressing colonial shackles in the curricula while others mask an attitude of resistance to change by academics. Heleta (2016:1) reported that some academics ask: 'what do they (black students) mean by decolonisation? Going back to the Stone Age? Teaching only about South Africa and Africa? Isolation from the rest of the world?' Modiri (2016:1) maintained that these cynical queries by mostly white academics demanding that students explain to them what decolonisation means, suggests their own illiteracy about the history and intellectual debates in their disciplines.

The vividness of colonial entanglement of universities is outlined by Mbembe (2015). He (Mbembe 2015) explained

1.Decolonial scholars refer to the enduring legacy of colonialism as 'coloniality' to distinguish it from colonialism as colonial rule under colonial administrations (Grosfoguel 2007) 
that the presence of colonial symbols that tell a history of black oppression suggests a celebration of that history. The maintenance of Eurocentric theories and models that hardly relate to African students' experience is nothing other than perpetuating foreignness as well as perpetuating propagation of colonialism. Universities have become systems of authoritative control through programmes, grading system, methods of credits, acceptable and unacceptable standards and complicity professional bodies that accentuate modes of colonial education. Mbembe (2015) therefore concluded that this Eurocentric tradition has become hegemonic. It also represses anything that is articulated, thought and envisioned outside those frames. Hence, higher education institutions must undergo a process of decolonisation of knowledge and of the university institution itself.

However, the scepticism to decolonisation expressed by some academics, whether black or white academics, should be acknowledged. Fanon (1963) is critical of decolonisation when taken as Africanisation, because it will result in merely the transferring of resources from white people to black middle class people who then maintain the unfair advantages of the colonial past. Mbembe (2015) used an example of Black Economic Empowerment (BEE) in South Africa on the way how it has been used as an instrument of looting by those in power. Therefore, using this example, it would be pointless if decolonisation of universities focused on increasing black academics who serve to maintain the same colonial system. Prinsloo (2016:165) rightly warned that decolonising universities is more than removing colonial and apartheid era symbols, increasing black academics and including African texts in the curriculum.

Fanon (1963) advised that true decolonisation is about selfownership, which is the creation of new forms of life. This entails reshaping people and turning human beings into craftsmen and craftswomen in reshaping matters and form. The reshaping is not about mimicking or imitating the Eurocentric models, but generate new ones that are relevant to people. It is about ending Eurocentric models and starting human history anew. For Fanon (1963), decolonisation is a violent phenomenon whose goal is replacing certain species of humans by another species of humans. Violence here does not refer to physical violence, but expending effort in pursuing the replacement process with vigour. New species refers to a new category of men and women who create new forms of life that govern and determine new futures.

Ngugi Wa Thiong'o (1981) views decolonisation as a process of seeing ourselves clearly in relationship to ourselves and to other people in the world. He added that decolonisation is not an event that happens once, but it is an ongoing process of seeing ourselves clearly. Ngugi Wa Thiong'o (1981) also added that decolonisation is about re-centring ourselves intellectually and culturally by redefining what the centre is which is Africa. He views decolonisation as rejecting the West as a centre of consciousness and cultural heritage and replace it with Africa. However, this does not imply closing the doors to Europe or other traditions, but rather redefining the centre (Mbembe 2015).

In assessing the decolonisation discourse, at least from Fanon (1963) and Ngugi Wa Thiong'o's (1981) perspectives, there seems to be a subtle contradiction. Ngugi Wa Thiong'o (1981) suggests not closing the doors to Europe and yet advocates for changing the centre. Surely there cannot be two centres. Africa, in this case, replaces the West. Fanon's notion of the creation of new life (1963) conjures up the notion of replacing one another. In light of our discussion context, without experience and lacking certainty of how a decolonised university curriculum looks like, scepticism and cynicism persists. It persists partly because of resistant white academics, but more so as a psychological response to cope with the fear and threat of an unknown. For instance, when one considers the history and developments in practical theology discussions, how could the notion of 'telling African stories that are not told' be a replacement of the historically established theories in practical theology? Thus, confusion and darkness arise when one tries to imagine a decolonised practical theology in the South African academy. To complicate the issue further, how can physics and mathematics be decolonised? Is translating content into IsiXhosa, IsiZulu, et cetera, into Afrikaans, sufficient decolonisation? It is because of the complexity in other disciplines that Prinsloo (2016) suggested that the humanities are more placed to lead the discussion. However, Kamanzi (2016) rejects the notion of some disciplines being more suited for decolonisation than others. He provided an argument from natural sciences which is his discipline. His argument is worth citing at length as it addresses the argument that decolonisation is not practical in other disciplines. Kamanzi (2016) maintained that:

The discipline of Electrical Engineering itself comes into being through a professionalisation of branches of applied physics and mathematics as means to further develop technology harnessing the phenomena of energy, electricity and electromagnetic waves. In the early South African context, the major economic drivers in the early stages of these departments would have been the generation and distribution of electrical energy, mining technology and military applications. All of these elements that shaped this emerging discipline are evidently not apolitical and formed as a response, to some extent, to the social, political and economic projects of the time. The pursuit then of a decolonised curriculum in this context must respond to the constraints of the existing economy and state pressures and answer fundamental questions around the 'role of the engineer' in the existing and future society in relation to the project of self-reliance in the pursuit of self-determination. For example, if the future society were to decide to weigh up whether to nationalise access and production of its resources, would engineering schools be prepared to foster graduates who could fulfil this task, or are our existing curricula and educational systems built on the assumption that reliance on external expertise will be provided, thus rendering, to some extent, self-determination a perpetually risky decision. (p. 2)

Kamanzi's argument (2016) dispels blockage of imagination, uncritical thinking and biased ways of exploring 
decolonisation of the current universities' systems. Stated differently, Kamanzi (2016:1-2) discourages lazy academics who do not want to renew, reform or engage with fresh contextual realities. Modiri (2016) rightly argued that the cynicism to decolonisation of universities (which I argue) partly arises from 'self-induced blockage of mind' by some academics who have limited exposure to the history and intellectual debates in their discipline. And if an academic is characterised by such illiteracy and ignorance, we dare ask: Is that individual worth a university tenure or appointment? The answer is no insofar as universities are considered a place of critical discussion, reflection, development of new modes of thinking and knowledge.

The argument thus far has highlighted at least four issues: first, the existence of colonial hegemonic shackles in South African universities that needs to be addressed; second, the proposed way of doing decolonisation, at least by Fanon (1963) and Ngugi Wa Thiong'o (1981); third, the cynicism encountered in pursuing decolonisation; and fourth, the illumined application possibility of decolonisation in all disciplines. The vexing question in decolonisation, however, is: How can it be done? While this question cannot be simplistically answered, some suggestions can be made. Nyathi (2016:1-2) maintains that the decolonisation project should not focus on what needs to be taken away. He added that decolonisation should strive for the best of both worlds not 'an either or' situation. He (Nyathi 2016:1-2) stated that 'if there is useful African knowledge then I want it, and if Western scientists have a cure for cancer I also want it'. This proposal by Nyathi seems simplistic and yet lays an important principle, namely that decolonisation should move to a common ground where ideas and knowledge are built on.

The proposal made by Nyathi (2016:1), however, suggests that academics are open, willing and comfortable to seamlessly embrace the two epistemological sources, but experience indicates the contrary. Heleta (2016) noted that the university curricula are largely steeped in Eurocentric modes that are dominated by white people. Therefore, from a position of genuine innocence, how could such academics effectively and meaningfully participate in decolonisation? With some white academics' limitation to the understanding of black people and Africa, there is a risk of academic reflection paralysis that could be counterproductive. For instance, how can a white academic teach the science of tokoloshi or witchcraft, which is a totally different worldview? I suggest that it is the reality of this threat to a productive university decolonisation process that many scholars advise that decolonisation of curricula is more than increasing black lecturers, prescribing more black African authors or even having more dialogues about African stuff (Heleta 2016; Mbembe 2015; Prinsloo 2016). It is also not about creating universities that are disengaged globally, but being global producers of knowledge. The knowledge should be relevant locally (in South Africa), continentally (Africa) and globally (the entire world) (Heleta 2016). Some lessons (both positive and negative) to avoid devastating failures can be learnt from
Kenya and East Africa where decolonisation started in the 1960s. For instance, Tanzania has made considerable progress in attempting to utilise Swahili as medium of instruction at university level. Thus, decolonisation in an academic environment is in the first place a paradigmatic issue and a new mind-set.

As a way forward, in view of the staffing situation where there are many white academics, the following proposals are suggested: first, there is need to review and revamp content that is currently being taught by questioning its relevance to African contextual realities; second, challenge academics' negative attitude towards Africa and encourage self-introspection (soul searching) by academics regarding their allegiance, commitment and attitude to African knowledge; third, include substantially useful and relevant readings about Africa; fourth, encourage academics to be informed (educated) on African issues and challenge them to develop relevant theories (Heleta 2016:1; Mbembe 2015:1-4). ${ }^{2}$ These starting points for decolonising universities are not a once off event, but an ongoing process of engagement. It is an engagement that challenges African academics and students to be conscious and engage with contextual realities. This should result in producing truly African academics and scholars in African 'pots'.

In view of the preceding discussion, the question that is posed is: How is decolonisation relevant to practical theological reflection? Dreyer (2017:3), citing other scholars such as Miller-McLemore (2012), noted that, although practical theology has spread to many other parts of the world from its origins in Europe and USA, it is still very much tied to its European past. He (Dreyer 2017:1-3) added that a quick glance at the Wiley-Blackwell companion to practical theology (Miller-McLemore 2012) or at the membership list of the International Academy of Practical Theology (IAPT) will confirm this domination. The epistemologies, ontologies and methodologies of practical theologians in the 'Southern' contexts are mostly absent from 'international' practical theological books such as the Wiley-Blackwell companion to practical theology (Miller-McLemore 2012). Therefore, noting Dreyer's argument, to guide a response to the posed question, Mbembe (2015) proposed two steps in what he called decolonisation in the future tense. The first step in engaging decolonisation is to critique the current situation. It is critique on dominant Eurocentric academic models that do not fully acknowledge the other thinking and knowledge producing subjects. The critique is a self-assessment or analysis of the 2.For another proposal on how to proceed in decolonising practical theology, Dreyer (2017:5-6) proposes an approach that he called epistemological justice in practical theology as a way of decolonising practical theology in three ways. The first proposal is to have a bigger picture rather than a narrow one where one considers the whole research ecosystem. I would rather call this the research value chain. One has to consider all facets of the research ecosystem. This means attending to aspects such as the funding of research (research grants), the publication of research (who owns and controls publication spaces) access to advanced degrees (who are our postgraduate and postdoctoral students), research networks, ethica (who are our postgraduate and postdoctoral students), research networks, ethical practices (issues regarding access, use of research), et cetera. The second proposa is to fully embrace the humanity of all participants to ensure that they meaningfully contribute rather than as mere subjects. This will enable their knowledge to shape researchers' approach. The third proposal is to actively and constructively seek to acknowledge the practical knowledge(s) of practitioners such as pastors involved with communities in daily ministerial practice. Their knowledge is often not written down. 
current existing situation. The second step is a recognition of the present academic model and its shortcomings (step 1) which should lead to concrete steps that contribute to the desired improvements. These two steps will inform the next two sections focusing on practical theology in light of decolonisation discussion and the proposed shifts towards attainment of decolonised practical theology. Thus, the next two sections avoid what Tuck and Yang (2012:1) called treating decolonisation as a metaphor when it is a practical reality. Hence, practical steps should be encouraged in practical theology for renewal and refocusing.

\section{Reflections on practical theology within the decolonisation discussion in South African universities}

Drawing from the previous decolonisation discussion, this section considers practical theology within the ongoing discussion of decolonisation in South African universities. The question is: What are some of the issues to consider in decolonisation of practical theology? Miller-McLemore (2012:20) usefully describes practical theology as referring to four distinct enterprises with different audiences or objectives. She (Miller-McLemore 2012) stated that practical theology is:

[a] discipline among scholars and an activity of faith among believers. And it has two other common uses: it is a method for studying theology in practice and it is a curricular area of sub disciplines in the seminary. Practical theology refers to an activity of believers seeking to sustain a life of reflective faith in the everyday life, a method or way of analyzing theology in practice used by religious leaders and by teachers and students across the theological curriculum, a curricular area in theological education focused on ministerial practice and subspecialties, and, finally, an academic discipline pursued by a smaller subset of scholars to support and sustain these first three enterprises. (p. 20)

Miller-McLemore (2012:20) noted that each of the aspects of practical theology points to different locations, that is, from daily life to the library, and fieldwork to classroom, congregation and community, academic guild and global context. These aspects are connected and interdependent. While the above outline by Miller-McLemore (2012) is insightful, it is her further comments about practical theology that are central to our decolonisation discussion. She (MillerMcLemore 2012:20) added that practical theology redefines what constitutes theological knowledge or wisdom and seeks theology for the masses. It explores the dissonance between professed beliefs and lived realities in a critical manner.

Congruence on the goal of practical theology and decolonisation of universities discourse can be clearly discerned. Decolonisation of universities is about creating universities that are relevant to African people's needs and aspirations in order to respond to national and continental needs (within a global context). This is about producing academic products that serve the masses. Converging with this goal is practical theology as theological knowledge and wisdom for the masses also. It is reflecting about theology that engages and contributes to addressing issues of 'the good of human race' (Williams 2011:2-4). To that end, Berinyuu (2005:153-154) argued that the current theologies in Africa are inadequate to address African challenges such as dictators, political and ethnic conflicts, violence, et cetera. The gap in engaging contemporary challenges in African public theology has resulted in the birth of African Reconstruction Theology. Gathogo (2007) encapsulates the mission of pursuing what is good in Africa as developing a theology of reconstruction to rebuild (address) the various challenges. The agenda of reconstruction is a shift from the liberation agenda of liberation theology with the central figure, Moses in the exodus event to Nehemiah with his agenda for rebuilding Jerusalem in ruins. In Nehemiah 2, Nehemiah assessed the situation of Jerusalem's ruins and developed a plan to address the situation. Gathogo (2007) and Mugambi (1995) therefore argued that the Nehemiah figure should inspire holistic engagement with various African issues such as bad governance, corruption and destructive spiritualties that are dubbed 'Sanballats' and 'Tobia' who hinder human flourishing.

However, it should be highlighted that African Reconstruction Theology driven by the Nehemiah hermeneutic prism has its weaknesses. It tends to simplistically draw on one paradigm, namely Nehemiah's leadership and Jerusalem construction, as a paradigm for an overall construction solution to complex problems. ${ }^{3}$ The strength of this theological approach is, nonetheless, its focus on avoiding to blame colonialism for every African problem and focus on solutions. It emphasises the task of 'constructing new ways of doing things' as a motif. The point being made is that reconstruction theology seems to provide a perspective for engaging in a decolonised practical theology. Therefore, practical theology, as a theology of action, should 'imagine and explore ways' of doing responsible reconstruction theology that addresses public issues (Cahalan \& Mikoski 2014:3; Louw 2008:17; Magezi 2016:6). Practical theology should respond to public issues. This construction agenda calls for a relevant and public practical theology (Bowers 2009:96-100; Bruyns 2015:460 which entails a decolonised practical theology. However, the question is: How does practical theology in South African universities contribute to this decolonisation mission? What are the colonial shackles that should be addressed by practical theology?

Practical theology in South Africa is evidently enmeshed in Eurocentric paradigms and transformation has been slow (Dreyer 2017). Just to mention a few, it is unlikely for one to attempt to write a practical theology thesis or dissertation without being influenced by scholars such as Osmer, Ricoeur, Fowler, Gerkin, Heitink, Browning, Van der Ven, Schweiter, Kumlehn, Gadamer, Poling, Bass or Anderson. Transformation in practical theology has been led by students in their research who has been questioning Eurocentric epistemological foundations (Dreyer 2017:4-6). The irony is that theological

3.This point warrants a separate detailed discussion which is not the focus of this article. Suffice to note that there are many other perspectives in biblical literature article. Suffice to note that there are many other perspectives in biblical literature
that could be employed in different situations to address the situation that will be that could be employed in different situations to address the situ
presenting itself than use Nehemiah as a 'silver bullet paradigm'. 
students and academics are comfortable to write dissertations in practical theology or a discipline such as pastoral care in Africa without engaging African scholars such as Mugambi, Njiroge, Kinoti, Gathogo, Getui, Maluleke, Bediako, and others. To further expose academics appetite for Eurocentric paradigms, one could ask: How many practical theology academics at our South African universities strive to forge partnerships with colleagues in the USA, Canada, Germany, UK and Netherlands, just to mention a few countries? And when academics succeed in finding a colleague from the West to collaborate with, they treasure it greatly. While this may sound like an overstatement, the point being made here is that, if practical theology reflection is not self-reflective and reflexive, operating within a colonial hegemonic framework tends to be the natural norm. Dreyer $(2016 ; 2017)$ maintained that it is critical for academics to be reflexive in their research. This reflexivity entails being conscious about ourselves (who we are) and our positionalities within the process of conducting research, academic and knowledge production.

The above point can be extrapolated to probe the extent to which South African academics are disposed to developing links and networks as a proxy of fostering a strong and deep African appreciation through collaborating with other African universities, for example in humanity disciplines. The question that could be posed is: How many practical theologians in South African universities have seriously explored partnerships with theological scholars in neighbouring African countries such as Botswana, Zimbabwe, Mozambique, Kenya, Nigeria, among others? The response is likely to be 'not many' although there are some initiatives being forged. These initiatives include collaborative initiatives such as Network for African Congregational Theology (NetACT) at Stellenbosch University, Circle of Concerned African Women Theologians, Pan African Network HIV \& AIDS (PACANET), African Network for Higher Education and Research HIV \& AIDS (ANHERTHA) and many others being forged by South African academics with institutions such as Tumaini University Makumira (Tanzania), Uganda Christian University (Uganda), and Ethiopian Graduate School of Theology (Ethiopia). The other notable collaboration is the establishment of a pastoral care journal The Pastoral Journal for Life Care and Spiritual Healing to publish research in Africa together with the Southern Americas. ${ }^{4}$ These initiatives indicate efforts to forge collaborations, but they still need to develop and be more popularised which will happen with time. While these efforts are commendable, they are in the early stages, for example the pastoral care journal mentioned above.

The low collaboration of South African practical theologians in participating in research or publications with other African countries is not unique to the theology discipline. The Centre for Higher Education Transformation (CHET) (2013) observed that 'while university networks have emerged in most continents around the world, until now no special network of research (intensive) universities has been established in Africa'. The reasons cited for non-participation is the highly uneven development of scientific research conducted throughout Africa, with a strong concentration of academic output in three countries, that is, South Africa, Nigeria and Egypt (CHET 2013). Evidently, there seems to be little effort in enforcing African epistemological foundations that are pertinent in developing a decolonised African knowledge. This state of poor engagement with other African scholars (CHET 2013), while focusing on partnering with Western colleagues, suggests an unconsciousness by academics regarding their deeply rooted Western inclination. This indicates a self-sustaining system of colonial hegemonic knowledge systems including practical theology by academics. This hegemonic situation is self-perpetuating unless there is reflexivity (Dreyer 2016) and academics' consciousness of their positionality of power (Muhammad et al. 2015). Noting the general superiority of South African universities because they produce the bulk of African research (CHET 2013), it can be extrapolated that South African academic colonial hegemonies tend to be also sustained by universities through viewing people with research partners in Western countries as having important collaborations while being lukewarm to collaborations with African partnerships.

Magezi's (2016) current article titled 'Reflection on pastoral care in Africa: Towards discerning emerging pragmatic pastoral ministerial responses', that was published in one of the South African journals, explored the centre of pastoral care in Africa. After surveying the terrain of pastoral care in Africa, Magezi (2016:4) stated that African pastoral care is fragmented and by implication it lacks a clear organising centre. While this argument makes sense, it arguably lacks insight on the emerging organising centre of pastoral care in Africa. There is an organising centre on pastoral care in Africa focusing on reconstruction in addition to what Masamba ma Mpolo (2013) called homo africanus principles, that is, sanctity of life, relation between illness, misfortune and sin, spirits and ancestors in the life of the community, and life experienced as a whole (Magezi 2016:3). A holistic pastoral care was inaugurated in 1990, when Bishop Desmond Tutu was the president of the All African Conference of Churches (AACC). This holistic pastoral care agenda hinged on a reconstruction agenda that was followed by publications dealing with broad African issues by scholars such as Mugambi (1995), Gathogo (2007), Nwachuku (1991; 2000) and others. This reconstruction agenda persists to this day among the guild members of that era such as Mugambi, Tutu, Kinoti, Gathogo, et cetera. Certainly, this limitation on important information by a Black African scholar, while possibly very proficient in Western paradigms as evidence from his other writings, indicates aspects that can be characterised as colonised hence requiring decolonisation. Therefore, Prinsloo (2016) advice is apt that decolonisation is far more than recruiting a black academic. Decolonisation requires overhauling the way academics think, do research and generate theories. As indicated above, decolonisation in an academic environment is, in the first place, a paradigmatic issue and a new mind-set. 
While the elements that require decolonisation of practical theology such as celebrating Western collaboration, prescribed books, analytical frameworks and staffing are clear, the challenge lies in outlining what a decolonised practical theology looks like. This takes us to the next discussion on considerations for a decolonised practical theology.

\section{Pointers for practical theology decolonisation consideration}

The question of a decolonised practical theology is a vexing one. It is difficult to describe and outline its tenets. How does a decolonised South African practical theology look? Goto (2014:34-37) in his essay titled 'Asian American practical theologies', contained in the monograph Opening the field of practical theology, highlighted the difficulty in articulating theologies that bear geographical connotations such as African practical theology, Asian practical theology and others. He argues that such theologies are difficult to articulate, because the geographical people are not homogenous. For instance, one cannot speak of homogenous Africa (Berinyuu 2005). Despite this difficulty, Goto (2014) offered a useful three points worth adapting in guiding our discussion of a decolonised practical theology. Firstly, practical theology should engage in a theological reflection in a manner that results in transformation. For instance, in our South African context, an engaged practical theology should result in engaging the colonial structures and its remnants as well as oppressive systems. Secondly, practical theology should make use of scholars in their context. This means practical theology in South Africa should use South African and African scholars' theories. The scholars do not necessarily need to be black students, but should reflect paradigmatic approach and mind-set that promote epistemologies and reflection approaches that engage with contemporary issues. For instance, an academic could juxtapose the approaches of Paul Ricoeur or Jurgen Habermas with African thoughts and draw ways of how one could do practical theology that draws and integrates their thoughts to African approaches. This way, the reflection intentionally integrates Western thought and African thought frameworks. Thirdly, practical theology knowledge and wisdom should derive from the people's wisdom and experiences.

In view of the fluidity in articulating a decolonised practical theology, the following pointers that build on Goto (2014) can be suggested as a starting point. A decolonised practical theology should include the following features:

1. It should seriously engage its context resulting in transformation. The opposite of transformation is maintenance of the colonial hegemonic status quo. A decolonised practical theology should embrace a mission of ongoing reflection and transformation of the various aspects of humanity and the discipline itself (selfreflective).

2. Practical theology should engage with scholarship in South Africa and African context. This includes critical engagement and prescribing reading materials, and learning from the people's experiences resulting in developing models informed by these people's contextual experiences.

3. Practical theology should draw its paradigms and models from people's wisdom and paradigms. This entails pursuing a theological approach that draws from African experiences. This can be explored as a way of bringing three epistemological spheres: theological, historical Western approaches, and African wisdom and experiences.

4. Practical theology should be self-critical of its centre and epistemological sources. It should ask questions about its motivations, agenda and contributions (re-centring, new life). This entails reflexivity (Dreyer 2016) and academics' consciousness of their positionality of power (Muhammad et al. 2015) resulting in intentional pursuit of agendas based on pressing challenges.

5. Practical theology should view itself as being in a continuous reformation and transformation. It is a process, not an event which should enable it to engage with issue on an ongoing basis.

To provide a complete picture of the possibilities and constraints of decolonisation of practical theology, the above proposed elements should be viewed in light of the persisting challenges. These challenges are stumps in the pathway.

\section{Stumps of the path to practical theology decolonisation process}

I take the metaphor of a stump to refer to an obstruction on the path to reaching your destination. These stumps destruct and divert. They are countering threats. The proposals for a decolonised practical theology would be incomplete without highlighting these countering forces or threats. Unfortunately, these countering forces are a 'elephant in the room' of practical theology in South African academy. 'Elephant in the room' is an idiom that means having a problem or risk that no one wants to discuss. I suggest the following three forces:

First, a focus on black African issues and a threat of compromised academic rigour: Whether perceived or real, there are observable elements of tension that exists between African scholars and the fluid unwritten standards in scholarship as evidenced by publications. Gifford (2008:31-33) in his essay 'Africa's inculturation theology: Observations of an outsider' observed that, in an effort for quick publications, some unpolished papers gets published by the mushrooming publishers. This has resulted to critical issues that require in-depth and theoretical reflection which remain neither explored nor academically considered in a systematic manner. Therefore, he hesitatingly stated that this situation has caused a deficiency in African theological reflection. Gifford's concern was echoed by one black African academic in a casual conversation at a PTSA conference. He quipped: ${ }^{5}$

5.It is noted that this article is not based on empirical research. However, this statement, verbalised by a black academic, provides an insight into how some academics perceive publishing. 
If you try to publish on a subject or anything with foundations in Western thinking your work will hardly get published. The critique will be harsh. Therefore, to overcome this hurdle I publish on African issues only. For instance, white people don't have experience in witchcraft so they can't reject my work.

This statement implies that publishing is controlled and guarded by white people who could use their positions to exclude black people and hence one should 'bust the system'. The above statement resonates with what Senokoane (2015:1) in his article 'A White Mist in the Black UNISA' referred to as 'institutional racism, otherwise known as white ethics' which positions itself as a standard or norm in the institution and at the same time places itself as the only good while other experiences and knowledge are bad and do not meet the standard. The destructive effect of this situation, perceived or real, is, if not managed, that unpolished research gets published by a weakened review system. It should be noted that some black academics tackle African contextual issues that have limited prior published research for benchmarking. ${ }^{6}$ This challenge tends to be compounded by weak academic language proficiency. In view of this situation, I suggest strong mentoring and coaching of young developing African scholars by senior black academics and white academics. Surely universities should live up to their status of generating knowledge, new theories and robust scholarship. The practical theologians, despite their race, who evades quality control and research output gatekeepers (publishers, reviewers and editors) who stifles certain knowledge or become gateways for poor practical theology research are deplorable and should be condemned (Kastrenakes 2013; Seife n.d.). ${ }^{7}$ This stands against the spirit of genuine decolonisation and generation of knowledge that can exported globally.

Second, there is NRF rating pressure to focus one's research and, yet, African challenges are broad and holistic. The question is: Is NRF a colonial hegemonic structure that requires decolonisation or is it leading to quality focused scholarship? The answer seems to lie at the middle, that is, balanced quality and focused scholarship (see NRF n.d.). This argument aptly presented by Dreyer (2017:5) and Pandey and Pattnaik (2015:172) who contended that the entire research ecosystem should be scrutinised, because it consists of human capital (e.g. the researchers), governance capital (e.g. the research policies), physical capital (e.g. the equipment to do the research or research facilities), intellectual capital (such as knowledge, information and ideas) and lastly financial capital (e.g. research grants and funding). All these systems easily reflect colonial residual practices (coloniality) and structures that should be changed.

Third, there is a trend of targeting international knowledge consumers and downplaying or downplaying African people's issues. Academics are pressured to publish

6.Dreyer (2017:5) proposes tapping on this practical knowledge of people on the ground that usually does not get published.

7.For fake peer review and poor research being published, see Kastrenakes (2013) and Seife (n.d.) internationally which means the debate and issues should be applied to global issues and yet the issues relate to a particular context. The idea that one is assessed by the impact of their work suggests that one should situate him- or herself globally; otherwise who will be interested in a rural community which is based, say, in New York or Berlin.

\section{Conclusion}

This article has discussed practical theology within South Africa's discussion of decolonisation of university curricula. It highlighted the need for a theology, particularly practical theology and pastoral care that increasingly assume a public role. A public role in South Africa entails developing a theology that genuinely engages with contemporary issues. To that end, reconstruction theology provides a useful nexus. However, for practical theology to effectively perform a reconstruction role, it should be practical and relevant to its context. Relevancy, among other things, entails shaking off the colonial shackles, that is, it requires decolonisation. As discussions for decolonised universities brews in South Africa, practical theology is equally faced with the same challenge. Far from being a simplistic project, decolonisation requires serious discipline introspection, academic reflection that is reflexive, and academics who are conscious of their positionality within the remnants of the colonial power matrix. This process is a journey, an ongoing experimenting with new ways of generating knowledge. Importantly, however, the decolonisation process entails an intentional process of doing theology at a plane with three interlocking interfaces: theology and its traditions, Western historical paradigms through which theology has been done thus far, and African wisdom and knowledge. From this perspective, practical theology becomes an open process of learning, unlearning and re-learning in the space of practical life where people yearn for disentanglement from colonial hangover.

\section{Acknowledgements Competing interests}

The author declares that he has no financial or personal relationships which may have inappropriately influenced him in writing this article.

\section{References}

Berinyuu, A.A., 2005, 'Doing public theology in Africa: Trends and challenges', in E. Graham \& A. Rowlands (eds.), Pathways to the public Square, pp. 147-156, Transaction Publishers, London.

Bowers, P., 2009, 'Christian intellectual responsibilities in modern Africa', Africa Journal of Evangelical Theology 28, 91-114.

Bruyns, C.L., 2015, 'The rebirth of Kairos theology and its implications for public theology and citizenship in South Africa', Missionalia 43(3), 460-477. https://doi. org/10.7832/43-3-131

Cahalan, K.A. \& Mikoski, G.S. (eds.), 2014, Opening the field of practical theology: An introduction, Rowan \& Littlefield, New York, NY.

Centre for Higher Education Transformation (CHET), 2013, African league of research universities, viewed 08 May 2017, from https://www.chet.org.za/.../Cloete $\% 20$ and $\% 2$ Maassen $\% 202013 \% 2$ League $\% 20$ of $\% 2$

Dreyer, J., 2016, 'Knowledge, subjectivity, (de)coloniality, and the conundrum of reflexivity', in J.A. Mercer \& B. Miller-McLemore (eds.), Conundrums in practical theology, pp. 90-109, Brill Academic Publisher, Leiden.

Dreyer, J.S., 2017, 'Practical theology and the call for the decolonisation of higher education in South Africa: Reflections and proposals', HTS Teologiese Studies/ Theological Studies 73(4), a4805. https://doi.org/10.4102/hts.v73i4.4805 
Dreyer, Y., 2004, 'A public practical theological theory for religious education of secularised youth', HTS 60(3), 919-945. https://doi.org/10.4102/hts.v60i3.615

Ernst \& Young, 2014, Transparency international, corruption perceptions index, viewed 01 April 2015, from www.transparency.org

Fanon, F., 1963, The wretched of the earth, François Maspero, Paris.

Gathogo, J., 2007, 'African theology of reconstruction as a practical theology for all', Practical Theology in South Africa 24(2), 99-121.

Gifford, P., 2008, 'Africa's inculturation theology: Observations of an outsider', Hekima Review 38, 18-34.

Goto, C., 2014, 'Asian American practical theologies', in K.A. Cahalan \& G.S. Mikoski (eds.), Opening up the field of practical theology, pp. 31-44, Rowman \& Littlefield, Maryland, UK

Grosfoguel, R., 2007, 'The epistemic decolonial turn', Cultural Studies 21(2), 211-223. https://doi.org/10.1080/09502380601162514

Heleta, S., 2016, Decolonisation: Academics must change what they teach, and how viewed 12 December 2016, from https://theconversation.com/decolonisationacademics-must-change-what-they-teach-and-how-68080

Juma, F., 2015, 'Public theology in the face of pain and suffering: A proletarian perspective', Consensus 36(2), 1-14, viewed 10 July 2015, from http://scholars. wlu.ca/consensus/vol36/iss $2 / 6$

Kamanzi, B., 2016, 'Decolonising the curriculum: The silent war for tomorrow', Daily Maverick, viewed 10 January 2017, from https://www.dailymaverick.co.za/ opinionista/2016-04-28-decolonising-the-curriculum-the-silent-war-foropinionista/2016-04-28-dec
tomorrow/\#.WHjKWoOaKUk

Kastrenakes, J., 2013, 'Sham science: Fake research paper accepted by over 100 journals', viewed 09 May 2017, from https://www.theverge.com/2013/10/3/ 4798840/fake-research-paper-exposes-poor-standards-open-access-journals

Koppel, M.S., 2015, 'Practicing public pastoral theologies in contexts of difference', Journal of Pastoral Theology 25(3), 151-152. https://doi.org/10.1080/10649867. 2015.1123923

Lartey, E.Y. \& Sharp, M.A.M., 2015, 'Practicing public pastoral theologies in contexts of difference', Journal of Pastoral Theology 25(3), 133-134. https://doi.org/10.1080 /10649867.2015.112350

Louw, D.J., 2008, Cura vitae: Illness and the healing of life in pastoral care and counselling, Lux Verbi, Cape Town.

Louw, D.J., 2014, Wholeness in hope care on nurturing the beauty of the Human sou in spiritual healing, LIT, Wien.

Magezi, V., 2016, 'Reflection on pastoral care in Africa: Towards discerning emerging pragmatic pastoral ministerial responses', In die Skriflig 50(1), a2130. https://doi. org/10.4102/ids.v50i1.2130

Maldonado-Torres, N., n.d., Outline of ten theses on coloniality and decoloniality, viewed $11 \mathrm{March}$ 2017, from http://frantzfanonfoundation-fondationfrantzfanon. $\mathrm{com} / \mathrm{IMG} / \mathrm{pdf} / \mathrm{maldonado-torres}$ _outline_of_ten_theses-10.23.16_.pdf

Masamba ma Mpolo, 2013, 'Spirituality and counselling for liberation: The context and praxis of African pastoral activities and psychology', in K. Federschmidt, K. Temme \& H. Weiss (eds.), Voices from Africa on pastoral care: Contribution in international seminars 1988-2008, pp. 7-18, Magazine of the Society for Intercultural Pastoral Care and Counselling (SIPCC), viewed 10 March 2016, from www1.ekir.de/sipcc/downloads/IPCC-020-txt.pdf

Mbembe, A., 2015, Decolonizing knowledge and the question of the archive, viewed 10 January 2016, from http://wiser.wits.ac.za/system/files/Achille\%20Mbembe $\% 20$ $\% 20$ Decolonizing $\% 20$ Knowledge $\% 20$ and $\% 20$ the $\% 20$ unestion $\% 20$ of $\% 20$ the $\% 20$ Archive.pdf

Mignolo, W., 2011, 'Modernity and decoloniality', in Oxford Bibliographies, viewed 02 September 2017, from http://www.oxfordbibliographies.com/view/document/ obo-9780199766581/obo-9780199766581-0017.xml

Miller-McLemore, B.J., 2005, 'Pastoral theology and public theology', in E. Graham \& A. Rowlands (eds.), Pathways to the public square, pp. 95-106, Transaction Publishers, London.

Miller-McLemore, B.J., 2012, 'Five misunderstandings about practical theology', International Journal of Practical Theology (IJPT) 16(1), 5-26. https://doi. org/10.1515/ijpt-2012-0002
Modiri, J., 2016, In the fall: Decolonisation and the rejuvenation of the academic project in South Africa, viewed 23 January 2016, from https://www. dailymaverick. co.za/opinionista/2016-10-16-in-the-fall-decolonisation-and-the-rejuvenationco.za/opinionista/2016-10-16-in-the-fall-decolonisation
of-the-academic-project-in-south-africa/\#.WIcfJbFh28U

Muhammad, M., Wallerstein, N., Sussman, A.L., Avila, M., Belone, L. \& Duran, B., 2015, 'Reflections on researcher identity and power: The impact of positionality on community based participatory research (CBPR) processes and outcomes', Crit Socio 41(7-8), 1045-1063. https://doi.org/10.1177/0896920513516025

Mugambi, J.N.K., 1995, From liberation to reconstruction: African Christian theology after the cold war, EAEP, Nairobi.

Ngugi Wa Thiong'o, 1981, Decolonising the mind: The politics of language in African literature, Zimbabwe Publishing House, Harare.

NRF, n.d., NRF Rating, viewed 08 May 2017, from http://www.nrf.ac.za/rating

Nussbaum, B., 2003, 'African culture and Ubuntu', Perspectives 17(1), 1-12.

Nwachuku, D.N., 1991, 'The situation of women in Africa in the process of adjustment and change', in K. Federschmidt, K. Temme \& H. Weiss (eds.), Voices from Africa on pastoral care: Contributions in international seminars 1988-2008, pp. 35-52, Magazine of the Society for Intercultural Pastoral Care and Counselling (SIPCC), viewed 10 March 2016, from www1.ekir.de/sipcc/downloads/IPCC-020(SIPCC),

Nwachuku, D.N., 2000, 'Creating communities through pastoral care and counselling in the fragmentations of urban African life', in K. Federschmidt, K. Temme \& $\mathrm{H}$. Weiss (eds.), Voices from Africa on pastoral care: Contributions in international seminars 1988-2008, pp. 97-106, Magazine of the Society for Intercultural Pastoral Care and Counselling (SIPCC), viewed 10 March 2016, from www1.ekir. Pastoral Care and Counselling (SIPCC),
de/sipcc/downloads/IPCC-020-txt.pdf

Nyathi, N., 2016, Decolonising the curriculum: The only way through the process is together, viewed 06 January 2017, from https://theconversation.com/ decolonising-the-curriculum-the-only-way-through-the-process-is-together69995

Osmer, R. \& Schweitzer, F., 2003, Religious education between modernization and globalization: New perspectives on the United States and Germany, Eerdmans, Grand Rapids, MI.

Pandey, S.C. \& Pattnaik, P.N., 2015, 'University research ecosystem: A conceptual understanding', Review of Economic and Business Studies 8(1), 169-181. https:// doi.org/10.1515/rebs-2016-0021

Pengo, P., 2011, 'The church in Africa: Mission and challenges', paper presented at the Inauguration Ceremony of the Research Area for Interdisciplinary Studies Related to African Culture, Pontifical Lateran University, viewed 09 January 2017, from https://zenit.org/articles/the-church-in-africa-mission-and-challenges/

Price, M. \& Ally, R., 2016, The challenge of decolonisation: UCT's transformation journey, viewed 11 January 2017, from http://www.politicsweb.co.za/news-andanalysis/the-challenge-of-decolonisation-ucts-transformation

Prinsloo, E.H., 2016, 'The role of the humanities in decolonising the academy', Arts \& Humanities in Higher Education 15(1), 164-168. https://doi.org/10.1177/ 1474022215613608

Seife, C., n.d., Science's big scandal- even legitimate publishers are faking peer review, viewed 09 May 2017, from http://www.slate.com/articles/health and science/ science/2015/04/fake_peer_review_scientific_journals_publish_fraudulent_ plagiarized_or_nonsense.htm

Sekhaulelo, M., 2016, 'The challenges facing the Dutch reformed churches in the South African liberal democracy', HTS Teologiese Studies/Theological Studies 72(1), a3031. https://doi.org/10.4102/hts.v72i1.3031

Senokoane, T., 2015, 'A white mist in the black UNISA', Scriptura 114(1), 1-11.

Tuck, E. \& Yang, K.W., 2012, 'Decolonisation is not a metaphor', Decolonisation: Indigeneity, Education \& Society 1(1), 1-40.

Vanhoozer, K.J. \& Strachan, O., 2015, The pastor as public theologian, Baker Academic, Grand Rapids, MI.

Williams, R., 2011, 'Relations between the church and state today: What is the role of the Christian citizen?', an address given at Manchester University, Manchester,
UK, viewed 10 January 2017, from http://rowanwilliams.archbishopofcanterbury. UK, viewed $10 \mathrm{January}$ 2017, from http://rowanwilliams.archbishopofcanterbury.
org/articles.php/2009/relations-between-the-church-and-state-today-what-isthe-role-of-the-christian-citizen 